\title{
ANALISIS PENGARUH GOOD CORPORATE GOVERNANCE TERHADAP NILAI PERUSAHAAN DENGAN CORPORATE SOCIAL RESPONSIBILITY SEBAGAI VARIABEL PEMODERASI (STUDI PADA INDEKS SRI-KEHATI YANG LISTED DI BEI)
}

\section{Iwan Kusuma Negara}

Faculty of Economics and Business, University of Mataram. Email : iwanegara@yahoo.com

\begin{tabular}{|c|c|}
\hline ARTICLE INFO & ABSTRACT \\
\hline $\begin{array}{l}\text { Keywords: } \\
\text { Good Corporate Governance, Corporate Social } \\
\text { Responsibility, Firm Value, Tobin's Q, } \\
\text { Regression Analysis, SRI-KEHATI Index. } \\
\text { Kata Kunci: } \\
\text { Tata Kelola Perusahaan yang Baik, Tanggung } \\
\text { Jawab Sosial Perusahaan, Nilai Perusahaan, } \\
\text { Tobin Q, Analisis Regresi, Indeks SRI-KEHATI. } \\
\text { How to cite: } \\
\text { Negara, Iwan Kusuma. (2019), Analisis } \\
\text { Pengaruh Good Corporate Governance Terhadap } \\
\text { Nilai Perusahaan Dengan Corporate Social } \\
\text { Responsibility Sebagai Variabel Pemoderasi } \\
\text { (Studi Pada Indeks Sri-Kehati Yang Listed di } \\
\text { BEI). JMM UNRAM, 8(1), 46-61 } \\
\text { DOI: } \\
\text { 10.29303/jmm.v8i1.408 }\end{array}$ & $\begin{array}{l}\text { This study aims to analyze the influence of Good Corporate } \\
\text { Governance (GCG) moderated by Corporate Social } \\
\text { Responsibility (CSR) toward firm value in the period of 2014- } \\
2016 \text { by using Moderated Regression Analysis method. The } \\
\text { population in this research consists of } 25 \text { firms listed in the } \\
\text { SRI-KEHATI Index which is an index on the Indonesia Stock } \\
\text { Exchange, formed by the biodiversity foundation (Kehati) by } \\
\text { prioritizing the principles of sustainability and social } \\
\text { responsibility.There are } 11 \text { firms selected as research samples } \\
\text { obtained by purposive sampling technique.The data used are } \\
\text { secondary data in the form of company annual report during } \\
\text { the study period, which published through website } \\
\text { wwww.idx.co.id. Hypotheses testing are conducted by t-test and } \\
\text { F-test. The results showed that GCG did not have a significant } \\
\text { effect on firm value as measured by Tobin's Q. Meanwhile, as } \\
\text { an independent variable, CSR disclosure gave an insignificant } \\
\text { negative effect on firm value.As a moderating variable, CSR } \\
\text { was able to strengthen the relationship between GCG and firm } \\
\text { value.This is because CSR disclosure is one form of } \\
\text { implementation of GCG, which means if the CSR disclosure } \\
\text { getting better, it also will make the GCG better. Eventually, it } \\
\text { will affect the change on firm value. } \\
\text { Penelitian ini bertujuan untuk menganalisis pengaruh } \\
\text { Good Corporate Governance (GCG) yang dimoderasi } \\
\text { oleh Corporate Social Responsibility (CSR) terhadap nilai } \\
\text { perusahaan pada periode 2014-2016 dengan } \\
\text { menggunakan metode Moderated Regression Analysis. } \\
\text { Populasi dalam penelitian ini terdiri dari } 25 \text { perusahaan } \\
\text { yang terdaftar dalam Indeks SRI-KEHATI yang } \\
\text { merupakan indeks di Bursa Efek Indonesia, yang }\end{array}$ \\
\hline
\end{tabular}




\section{PENDAHULUAN}

Masuknya pengaruh global juga memengaruhi perkembangan bisnis di Indonesia. Sesuai dengan perkembangan zaman dan teknologi yang semakin pesat, menyebabkan munculnya berbagai metode bisnis dan tren bisnis yang semakin berkembang, yang mana akan memiliki ciri khasnya sendiri pada setiap masa (Murwaningsari, 2009). Namun, hingga saat ini Indonesia belum bisa dikatakan sebagai negara dengan iklim bisnis yang baik. Keadaan tersebut tercermin dalam laporan peringkat indeks Doing Business 2016 yang diterbitkan oleh Bank Dunia. Dalam laporan tersebut, Indonesia berada pada posisi 109 dari 164 negara yang terdaftar.

Salah satu masalah yang paling besar dalam dunia bisnis Indonesia adalah banyaknya fraud atau kecurangan seperti praktik korupsi, penyalahgunaan aktiva/kekayaan organisasi serta kecurangan laporan keuangan yang menyebabkan terjadinya kerugian bagi pemerintah maupun perusahaan swasta di Indonesia. Dari hasil Survai Fraud Indonesia (SFI) yang dilakukan oleh Association of Certified Fraud Examiners (ACFE) Indonesia pada tahun 2016, tercatat telah terjadi 229 kasus fraud yang terdiri dari 178 kasus korupsi, 41 kasus penyalahgunaan aktiva dan 10 kasus kecurangan laporan keuangan yang menimbulkan kerugian mencapai puluhan miliar Rupiah.

Adanya konsep Good Corporate Governance (GCG) yang merupakan suatu sistem untuk mengarahkan dan mengendalikan suatu korporasi atau perusahaan, penerapan mekanisme GCG dapat meningkatkan kualitas laporan keuangan dari suatu perusahaan sehingga meminimalisir fraud (Setyaningrum, 2012). Komite Nasional Kebijakan Corporate Governance (KNKG) menyatakan bahwa suatu tata kelola perusahaan mengandung lima prinsip utama yaitu keterbukaan (transparency), akuntabilitas (accountability), tanggung jawab (responsibility), 
independensi (independency) dan kewajaran (fairness). Namun, perkembangan suatu perusahaan yang hanya mengutamakan kepentingan pemilik modal dapat menyebabkan terjadinya kesenjangan sosial dan kerusakan lingkungan sekitar. Untuk mengurangi dampak negatif yang ditimbulkan perusahaan, maka diperlukan CSR yang merupakan wujud kesadaran perusahaan untuk peduli terhadap lingkungan sekitarnya (Hamdani, 2016).

Hasil penelitian yang dilakukan oleh Research Centre for Governance, Institutions and Organization National University of Singapore (NUS) yang dipublikasikan pada acara Conference on Corporate Governance and Responsibility tahun 2016, memaparkan bahwa tingkat pelaporan CSR perusahaan-perusahaan di Indonesia tergolong tinggi. Namun, jika dilihat dari kualitas implementasinya masih tertinggal bila dibandingkan dengan Thailand dan Singapura. CSR mempunyai keterkaitan yang erat dengan GCG, keduanya memiliki kedudukan yang kuat dalam dunia bisnis namun berhubungan satu sama lain. Corporate Social Responsibility berorientasi kepada para stakeholders, hal ini sejalan dengan prinsip-prinsip utama Good Corporate Governance yaitu responsibility, sedangkan pengungkapan pelaksanaan Corporate Social Responsibility perusahaan sejalan dengan prinsip transparansi (Murwaningsari, 2009).

Suatu perusahaan akan mengungkapkan informasi apabila informasi tersebut dapat meningkatkan nilai perusahaan (Firm value). Nilai perusahaan merupakan kondisi tertentu yang telah dicapai oleh suatu perusahaan sebagai gambaran dari kepercayaan masyarakat terhadap perusahaan setelah melalui suatu proses kegiatan selama beberapa tahun, yaitu sejak perusahaan tersebut didirikan sampai dengan saat ini (Afzal, 2012). Meningkatnya nilai perusahaan adalah sebuah prestasi, yang sesuai dengan keinginan para pemiliknya (Stockholders), karena dengan meningkatnya nilai perusahaan, maka kesejahteraan para pemilik juga akan meningkat. Nilai perusahaan sangat penting karena dengan nilai perusahaan yang tinggi akan diikuti oleh tingginya kemakmuran pemegang saham (Gapensi, 1996; Kusumadilaga, 2010).

Penelitian mengenai faktor-faktor yang mempengaruhi nilai perusahaan (Firm value), sesungguhnya telah banyak dilakukan, tetapi terdapat perbedaan temuan antara hasil penelitian yang satu dengan yang lainnya. Penelitian Hanum (2012), Retno dan Denies (2012), Puspaningrum (2014) dan Julianty (2015) menunjukkan bahwa Good Corporate Governance dan Corporate Social Responsibility memiliki pengaruh yang signifikan terhadap nilai perusahaan. Namun demikian, temuan tersebut berbeda dengan temuan Lutfiah (2012), Kinanti (2015) serta Prastuti dan Budiasih (2015) yang menyatakan bahwa GCG dan CSR tidak berpengaruh signifikan terhadap nilai perusahaan.

Beberapa studi empirik sebagaimana dikemukakan di atas menyajikan hasil yang berbeda-beda tentang pengaruh GCG dan CSR terhadap nilai perusahaan. Research gap tersebut menjadi alasan utama bagi peneliti untuk mengkaji lebih dalam variabel-variabel dalam penelitian tersebut guna mengkonfirmasi kembali temuan dari berbagai penelitian terdahulu dengan menggunakan Indeks SRI-KEHATI sebagai objek penelitian. Indeks SRIKEHATI mengacu pada tata cara Sustainable and Responsible Investment (SRI) dengan nama Indeks SRI-KEHATI. Tujuan dibentuknya indeks ini adalah untuk memberikan informasi secara terbuka kepada masyarakat luas mengenai perusahan-perusahaan yang telah mengedepankan konsep CSR dan keberlanjutan di Indonesia. Dengan terbentuknya indeks ini, diharapkan perusahaan akan semakin terpacu untuk mengedepankan penerapan konsep GCG serta pengungkapan CSR sebagai salah satu faktor penting untuk meningkatkan nilai perusahaan. 


\section{NATIONALLY ACCREDITED JOURNAL - DECREE NO. 21/E/KPT/2018}

Perusahaan terpilih pada indeks SRI KEHATI yang dianggap memiliki bermacam bentuk pertimbangan dalam usahanya berkaitan dengan kepedulian pada lingkungan, tata kelola perusahaan, keterlibatan masyarakat, sumber daya manusia, hak asasi manusia, dan perilaku bisnis dengan etika bisnis yang diterima di tingkat international. Dari ratusan perusahaan yang terdaftar di Bursa Efek Indonesia (BEI), Yayasan Keanekaragaman Hayati menetapkan 25 (dua puluh lima) perusahaan terpilih yang dianggap dapat memenuhi kriteria untuk masuk dalam indeks SRI-KEHATI.

Namun, berbagai prinsip yang dilaksanakan oleh perusahaan yang tergabung pada indeks SRI KEHATI tidak semata-mata menjamin bahwa nilai saham perusahaan-perusahaan tersebut akan lebih baik dibandingkan dengan perusahaan lain atau dengan indeks lainnya. Berikut adalah data perbandingan perubahan rata-rata harga saham pada Indeks SRI KEHATI serta data rata-rata perubahan harga saham seluruh indeks yang terdaftar di BEI periode 20142016:

Gambar 1. Perubahan Harga Saham SRI KEHATI vs Rata-rata Indeks di BEI

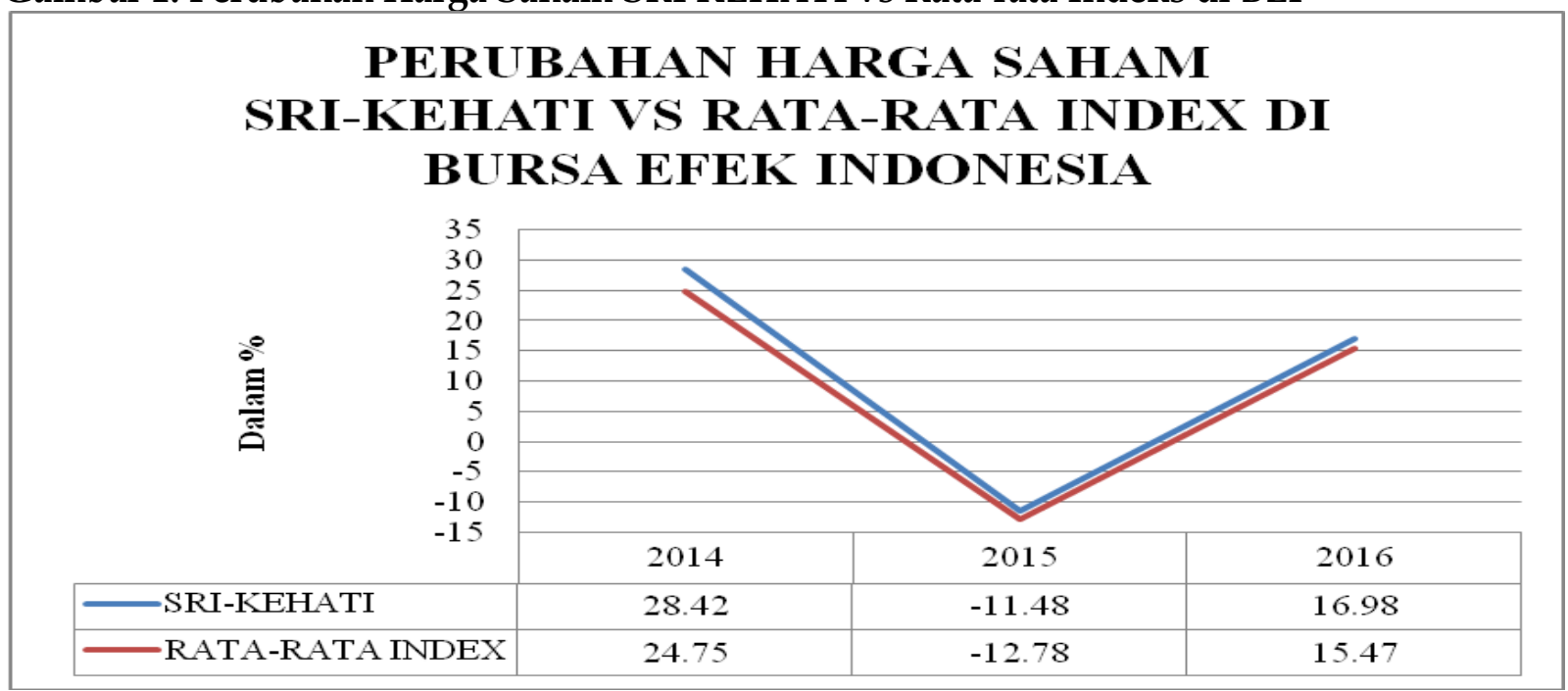

Sumber: Data Sekunder Diolah

Harga saham merupakan cerminan dari berbagai kebijakan yang diambil oleh manajemen dalam upaya meningkatkan nilai perusahaan melalui peningkatan kemakmuran para pemegang saham (Brigham \& Houston, 2006). Secara rata-rata, persentase perubahan harga saham pada Indeks SRI KEHATI selalu lebih baik setiap tahunnya selama periode 20142016 bila dibandingkan dengan persentase rata-rata perubahan harga saham pada seluruh indeks di BEI. Sehingga, informasi tersebut dapat menjadi dasar pemikiran bahwa Indeks SRI KEHATI yang menggunakan prinsip keberlanjutan, keuangan, tata kelola yang baik serta kepedulian terhadap lingkungan hidup, memiliki nilai perusahaan yang baik pula.

\section{TUJUAN PENELITIAN}

Tujuan yang ingin dicapai dalam penelitian ini adalah sebagai berikut :

1. Untuk mengetahui pengaruh Good Corporate Governance (GCG) terhadap nilai perusahaan.

2. Untuk mengetahui pengaruh Corporate Social Responsibility (CSR) terhadap nilai perusahaan.

3. Untuk mengetahui pengaruh GCG dan CSR secara simultan terhadap nilai perusahaan. 


\section{NATIONALLY ACCREDITED JOURNAL - DECREE NO. 21/E/KPT/2018}

4. Untuk mengetahui pengaruh GCG terhadap nilai perusahaan dengan moderasi CSR.

\section{LANDASAN TEORI}

\subsection{Good Corporate Governance}

Konsep Good Corporate Governance (GCG) memastikan bahwa pihak manajemen dari perusahaan yang banyak bergantung pada modal eksternal untuk melaksanakan kegiatan operasional, melakukan investasi, dan menciptakan pertumbuhan perusahaan, menggunakan dana-dana tersebut secara tepat dan efisien serta bertindak yang terbaik bagi kepentingan perusahaan (Sutedi, 2012). GCG adalah suatu sistem yang mencakup sebuah proses untuk dapat mengendalikan setiap kegiatan di dalam perusahaan, serta untuk dapat memberikan pertanggungjawaban kepada pihak shareholders khususnya dan stakeholders pada umumnya, yang berlandaskan pada nilai, etika dan peraturan perundang-undangan.

Prinsip GCG yang dikemukakan oleh Daniri (2014) selaras dengan Keputusan Menteri BUMN Nomor 117/2002 mengenai Good Corporate Governance, yaitu (1)Transparency (Keterbukaan), (2) Accountability (Akuntabilitas), (3) Responsibility (Pertanggungjawaban), (4) Independency (Kemandirian), dan (5) Fairness (Kewajaran). GCG diharapkan dapat mengatasi agency problem dengan memberi keyakinan kepada para investor bahwa mereka akan menerima return atas dana yang telah diinvestasikan. Aspek GCG meliputi yaitu kepemilikan manajerial, proporsi komisaris independen, kepemilikan institusional dan komite audit.

Kepemilikan Manajerial. Jensen dan Meckling (1976) dalam Indahningrum (2009) menyatakan bahwa mekanisme untuk mengatasi konflik keagenan antara lain meningkatkan kepemilikan insider (insider ownership) sehingga dapat mensejajarkan kepentingan pemilik dengan manajer. Kepemilikan manajerial adalah besarnya saham yang dimiliki manajemen dari total saham yang beredar. Kepemilikan manajerial juga dapat dikatakan sebagai situasi yang di dalamnya manajer sekaligus sebagai pemegang saham perusahaan yang ditunjukkan dengan persentase kepemilikan saham perusahaan oleh manajer. Kepemilikan saham yang besar dari segi nilai ekonomisnya memiliki insentif menyelaraskan kepentingan agent dan principal.

Kepemilikan Institusional. Kepemilikan institusional adalah besarnya jumlah saham yang dimiliki institusi dari total saham beredar. Adanya kepemilikan institusional dapat memantau secara profesional perkembangan investasinya sehingga tingkat pengendalian terhadap manajemen sangat tinggi yang pada akhirnya dapat menekan potensi kecurangan. Pemegang saham institusional diantaranya mencakup perusahaan asuransi, dana pensiun dan reksadana. Semakin besar kepemilikan institusional maka semakin efisien pemanfaatan aset perusahaan dan diharapkan juga dapat bertindak sebagai pencegah terhadap pemborosan yang dilakukan oleh manajemen (Faisal, 2005).

Proporsi Dewan Komisaris Independen. Komisaris independen adalah anggota dewan komisaris yang tidak terafiliasi dengan manajemen, anggota dewan komisaris lainnya dan pemegang saham pengendali, bebas dari hubungan bisnis atau hubungan lainnya yang dapat mempengaruhi kemampuannya untuk bertindak independen atau bertindak semata-mata sesuai kepentingan perusahaan (Rachmad, 2012). Menurut Peraturan Pencatatan nomor IA tentang Ketentuan Umum Pencatatan Efek bersifat Ekuitas di Bursa yaitu jumlah komisaris independen minimum 30\%. Dalam rangka penyelenggaraan pengelolaan perusahaan yang baik (GCG), dewan komisaris tidak boleh melibatkan diri dalam tugas-tugas manajemen dan 
tidak boleh mewakili perusahaan dalam transaksi-transaksi dengan pihak ketiga. Anggota dewan komisaris diangkat dan diganti dalam Rapat Umum Pemegang Saham (RUPS).

Komite Audit. Berdasarkan kerangka hukum di Indonesia, perusahaan-perusahaan publik diwajibkan untuk membentuk komite audit. Menurut Kepmen Nomor 117 tahun 2002, tujuan dibentuknya komite audit adalah membantu komisaris atau dewan pengawas dalam memastikan efektifitas pelaksanaan tugas auditor internal dan auditor eksternal. Sejalan dengan arahan untuk menjalankan fungsi komite audit secara efektif, maka ukuran sukses komite audit yang berhubungan dengan kegiatan organisasi adalah untuk memenuhi kebutuhan konsumen seperti pelayanan, kualitas dan biaya (Hamdani, 2016).

\subsection{Tanggung Jawab Sosial Perusahaan (Corporate Social Responsibility)}

Corporate Social Responsibility (CSR) adalah suatu bentuk perwujudan dari komitmen yang dimiliki oleh perusahaan dalam rangka mensejahterakan masyarakat atas dasar kesadaran bahwa keberadaan perusahaan merupakan bagian yang tidak terpisahkan dari masyarakat. Setiap perusahaan memiliki pandangan dan sikap atau respon yang berbeda terhadap penerapan dan pengungkapan CSR. Tisnawati dan Saefullah (2005) mengungkapkan beberapa sikap atau strategi yang diambil oleh perusahaan mengenai CSR, yaitu (1) Strategi reaktif, (2) Strategi defensif, (3) Strategi akomodatif, dan (4) Strategi proaktif.

Konsep pelaporan CSR digagas di dalam Global Reporting Inisiative (GRI). Dalam GRI Guidelines disebutkan bahwa perusahaan harus menjelaskan dampak dari aktivitas yang dilakukan terhadap ekonomi, lingkungan, praktek tenaga kerja, masyarakat dan Tanggung jawab produk, dimana di dalamnya terdapat penjelasan sejumlah 79 item yang terdiri atas 7 Aspek utama (Puspaningrum, 2014) yaitu (1) Aspek Lingkungan, terdiri dari 13 item, (2) Aspek Energi, terdiri dari 7 item, (3) Aspek Kesehatan dan Keselamatan Tenaga Kerja, terdiri dari 8 item, (4) Aspek Ketenagakerjaan, terdiri dari 29 item, (5) Aspek Tanggung Jawab Produk, terdiri dari 10 item, (6) Aspek Keterlibatan Masyarakat, terdiri dari 9 item, dan (7) Aspek Umum, terdiri dari 2 item.

\subsection{Nilai Perusahaan (Firm Value)}

Nilai perusahaan dapat menunjukkan nilai asset yang dimiliki perusahaan seperti suratsurat berharga, salah satunya adalah saham. Saham (Stock) merupakan salah satu asset berharga yang dikeluarkan oleh perusahaan. Nilai perusahaan go public selain menunjukkan nilai seluruh aktiva, juga tercermin dari nilai pasar atau harga sahamnya, sehingga semakin tinggi harga saham mencerminkan tingginya nilai perusahaan (Afzal, 2012).

Salah satu proxy dalam mengukur nilai perusahaan adalah dengan menggunakan Tobin's Q. Rumus ini dikembangkan oleh Professor James Tobin. Rasio ini merupakan konsep yang sangat berharga karena menunjukkan estimasi pasar keuangan saat ini tentang nilai hasil pengembalian dari setiap dolar investasi inkremental. Tobin's $Q$ dihitung dengan membandingkan rasio nilai pasar saham perusahaan dengan nilai buku ekuitas perusahaan.

\subsection{Teori Keagenan (Agency Theory)}

Teori keagenan merupakan basis teori yang mendasari praktik bisnis perusahaan yang digunakan selama ini. Teori tersebut berakar dari sinergi teori ekonomi, teori keputusan, sosiologi dan teori organisasi. Prinsip utama teori ini menyatakan adanya hubungan kerja antara pihak yang memberi wewenang yaitu investor dengan pihak yang menerima 


\section{NATIONALLY ACCREDITED JOURNAL - DECREE NO. 21/E/KPT/2018}

wewenang (agensi) yaitu manajer. Agency Theory atau teori keagenan adalah pendesainan kontrak yang tepat untuk menyelaraskan kepentingan prinsipal dan agen dalam hal terjadinya konflik kepentingan (Scott, 1997).

\subsection{Stewardship Theory}

Teori stewardship adalah teori yang menggambarkan situasi dimana para manajer tidaklah termotivasi oleh tujuan-tujuan individu tetapi lebih ditujukan pada sasaran hasil utama mereka untuk kepentingan organisasi, sehingga teori ini mempunyai dasar psikologi dan sosiologi yang telah dirancang dimana para eksekutif sebagai steward termotivasi untuk bertindak sesuai keinginan principal. selain itu perilaku steward tidak akan meninggalkan organisasinya sebab steward berusaha mencapai sasaran organisasinya. Teori ini didesain bagi para peneliti untuk menguji situasi dimana para eksekutif dalam perusahaan sebagai pelayan dapat termotivasi untuk bertindak dengan cara terbaik pada principalnya (Donaldson dan Davies, 1991; Anton, 2014).

\section{RERANGKA KONSEPTUAL DAN PENGEMBANGAN HIPOTESIS}

\subsection{Rerangka Konseptual}

GCG sebagai variabel independen akan diproksikan dengan Kepemilikan Manajerial, Kepemilikan Institusional, Proporsi Dewan Komisaris dan Komite Audit. Kombinasi dari keempat proxy tersebut akan mewakili nilai GCG, karena variabel GCG tidak memiliki nilai sendiri. Selanjutnya CSR akan dihitung menggunakan formula Corporate Social Responsibility Disclosure (CSRD) dan nilai perusahaan diukur dengan rumus Tobin's Q. Penelitian ini akan mengungkapkan pengaruh GCG $\left(\mathrm{X}_{1}\right)$ dan CSR $\left(\mathrm{X}_{2}\right)$ terhadap nilai perusahaan $(\mathrm{Y})$ secara simultan dan parsial. CSR dalam penelitian ini merupakan variabel moderasi yang akan memperkuat atau memperlemah hubungan dari variabel bebas terhadap variabel terikat. Dengan demikian, rerangka konseptual dalam penelitian ini adalah sebagai berikut :

\section{Gambar 2. Rerangka Konseptual}

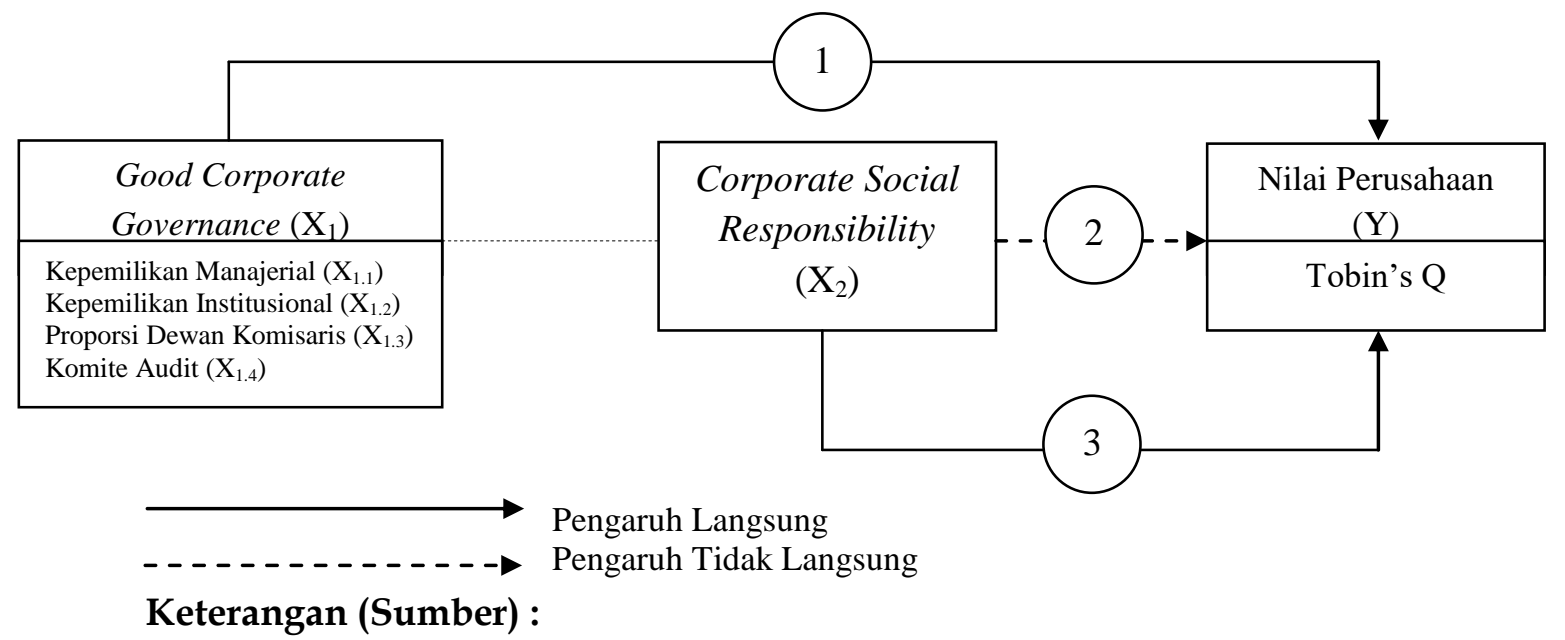

1) Jensen dan Meckling (1976), Faisal (2005), Hanum (2012), Wida dan Suarta (2014), Kinanti (2015), Julianti (2015), Stewardship Theory, Stakeholders Theory.

2) Kokubu et al. (2011), Agency Theory, Stewardship Theory, Stakeholders Theory. 
3) Rustiriani (2010), Retno dan Denies (2012), Setiawan (2013), Mardikanto (2014), Agency Theory.

\subsection{Pengembangan Hipotesis}

\subsubsection{Pengaruh GCG terhadap Nilai Perusahaan}

Kepemilikan manajerial akan meningkatkan kinerja manajer dalam upaya peningkatan nilai perusahaan (Jensen dan Meckling, 1976), kemudian adanya Kepemilikan Institusional akan mampu meningkatkan pengawasan terhadap kinerja manajer perusahaan tersebut (Faisal, 2005), selanjutnya semakin besarnya Proporsi Dewan Komisaris Independen dalam suatu perusahaan akan dapat meningkatkan Kinerja Manajerial, Komite Audit dalam Kepmen Nomor 117 tahun 2002 akan berlaku untuk meningkatkan efektifitas auditor. Temuan Hanum (2012), Wida dan Suarta (2014), Kinanti (2015) dan Julianti (2015) menunjukkan bahwa GCG yang diproksikan dengan Kepemilikan Manajerial, Kepemilikan Institusional, Proporsi Dewan Komisaris dan Komite Audit berpengaruh positif terhadap nilai perusahaan. Temuan tersebut sejalan dengan Stakeholders Theory dan Stewarship Theory dimana perusahaan menjaga hubungan dengan pemilik modal (Stockholders) dengan meningkatan nilai perusahaan melalui peningkatan harga saham. Dengan demikian, dapat dirumuskan hipotesis sebagai berikut:

$\mathrm{H}_{1}$ : GCG berpengaruh positif terhadap nilai perusahaan.

\subsubsection{Pengaruh CSR terhadap Nilai Perusahaan}

Terbentuknya konsep GCG serta pengungkapan CSR memiliki tujuan yang sama yaitu meningkatkan nilai perusahaan (Firm value) dan memberikan keuntungan atau berbagai manfaat bagi shareholders dan stakeholders. Apabila suatu perusahaan berkeinginan untuk meningkatkan nilai perusahaan, maka perusahaan harus mempertimbangkan berbagai masalah sosial dan lingkungan dalam pengambilan keputusannya (Mardikanto, 2014). Penelitian Setiawan (2013) menunjukkan bahwa investor mengapresiasi informasi pengungkapan CSR untuk pengambilan keputusan sehingga hal tersebut dapat menaikkan nilai perusahaan. Selanjutnya, penelitian Retno dan Denies (2012) menyatakan bahwa pengungkapan CSR berpengaruh positif terhadap nilai perusahaan. Berdasarkan uraian di atas, maka rumusan hipotesis dalam penelitian ini adalah :

\subsubsection{Pengaruh GCG dan CSR terhadap Nilai Perusahaan}

$\mathrm{H}_{2}$ : CSR berpengaruh positif terhadap nilai perusahaan.

Penganut paham corporate governance menerima kebutuhan dan kewajiban melaksanakan CSR karena kedua kegiatan tersebut berlandaskan pemahaman falsafah yang sama. Corporate governance menyangkut tanggung jawab perusahaan kepada pihak-pihak lain yang berkepentingan terutama atas kegiatan ekonomi dan segala dampaknya, sedangkan CSR adalah kegiatan menaikkan tingkat kesejahteraan masyarakat di luar kegiatan utama perusahaan. Kedua kegiatan tersebut sama-sama bertujuan untuk mengoptimalkan nilai perusahaan bagi pemegang saham namun tetap memperhatikan pemangku kepentingan lainnya (Zarkasyi, 2008; Rustiarini, 2010). Hasil penelitian Rustiarini (2010), Retno dan Denies (2012) menunjukkan bahwa GCG dan pengungkapan CSR memiliki pengaruh positif dan signifikan terhadap nilai perusahaan. Dengan demikian, berdasarkan pemaparan di atas dapat dirumuskan hipotesis sebagai berikut :

$\mathrm{H}_{3}$ : GCG dan CSR secara simultan berpengaruh terhadap nilai perusahaan. 


\subsubsection{Pengaruh GCG terhadap Nilai Perusahaan dengan Moderasi CSR}

Kombinasi dari GCG, CSR dan moderasi antara keduanya akan mampu memberikan pengaruh yang lebih kuat terhadap nilai perusahaan. Sebagaimana yang telah dijelaskan sebelumnya melalui berbagai teori, definisi serta dukungan penelitian terdahulu bahwa ketiga hal tersebut masing-masing akan mampu meningkatkan nilai perusahaan. Sehingga kombinasi antar ketiga hal tersebut secara bersama-sama juga akan mampu memperkuat nilai perusahaan dengan lebih komperhensif. Secara teoretis, terdapat hubungan positif antara kinerja ekonomi suatu perusahaan dengan pengungkapan tanggung jawab sosial (Kokubu et. al, 2001; Sembiring, 2005; Retno dan Denies, 2012). Hal ini didukung oleh Agency theory dengan premis bahwa perolehan laba yang semakin besar akan membuat perusahaan mengungkapkan informasi sosial yang lebih luas. Berdasarkan uraian di atas maka dapat diajukan hipotesis sebagai berikut :

$\mathrm{H}_{4}$ : CSR mampu memperkuat pengaruh GCG terhadap nilai perusahaan.

\section{METODE PENELITIAN}

\subsection{Jenis Penelitian, Populasi dan Sampel}

Jenis penelitian yang digunakan dalam penelitian ini adalah penelitian kuantitatif dengan pendekatan asosiatif. Populasi dalam penelitian ini berjumlah sebanyak 25 perusahaan dalam indeks SRI-KEHATI yang terdaftar di BEI periode 2014-2016. Penentukan sampel menggunakan teknik purposive sampling, sehingga diperoleh sampel sebanyak 11 perusahaan.

\subsection{Variabel Penelitian dan Definisi Operasional Variabel}

Good Corporate Governance (GCG) diukur dengan empat proxy yaitu :

1. Kepemilikan Manajerial

Kepemilikan Manajerial (KM) diukur dengan membandingkan jumlah saham yang dimiliki manajer dengan jumlah saham yang beredar. Jumlah saham yang dimiliki manajer adalah total keseluruhan jumlah saham yang dimiliki oleh jajaran komisaris dan direksi perusahaan. Sementara, jumlah saham yang beredar adalah total saham biasa. Formula yang digunakan (Jensen dan Meckling, 1976) adalah sebagai berikut :

2. Kepemilikan Institusional

$$
K M=\frac{\text { Jumlah Saham yang Dimiliki Manajer }}{\text { Jumlah Saham yang Beredar }} \times 100
$$

Kepemilikan Institusional (KI) diukur dengan membandingkan jumlah saham yang dimiliki oleh institusi dengan jumlah saham yang beredar. Saham yang dimiliki oleh Institusi adalah total keseluruhan jumlah saham yang dimiliki oleh organisasi atau perusahaan lain serta lembaga pemerintahan. Rumus yang digunakan (Faisal, 2005) adalah sebagai berikut :

$$
K I=\frac{\text { Jumlah Saham yang Dimiliki Institusi }}{\text { Jumlah Saham yang beredar }} \times 100
$$

3. Proporsi Dewan Komisaris

Proporsi Dewan Komisaris dapat dilihat dari rasio persentase antara jumlah komisaris yang berasal dari luar perusahaan dan tidak terafiliasi oleh direksi (Independen) terhadap total jumlah anggota dewan komisaris perusahaan. Rumus yang digunakan untuk mengukur Proporsi Dewan Komisaris (Rachmad, 2012) adalah: 
4. Komite Audit

$$
P D K=\frac{\text { Jumlah Komisaris Independen }}{\text { Jumlah Seluruh Anggota Dewan Komisaris }} \times 100
$$

Komite audit merupakan persentase jumlah anggota komite yang berasal dari luar perusahaan terhadap jumlah seluruh anggota komite audit perusahaan. Untuk mengukur Komite Audit (KA), maka digunakan formula (Hamdani, 2016) yaitu :

$$
K A=\frac{\text { Jumlah Anggota Komite Audit Dari Luar }}{\text { Jumlah seluruh Anggota Komite Audit }} \times 100
$$

Kemudian pengukuran nilai perusahaan menggunakan Tobin's Q. Rasio Tobin's Q dihitung dengan cara membandingkan rasio nilai pasar saham perusahaan dengan nilai buku ekuitas perusahan (Weston dan Copeland, 2004). Adapun Rumus Tobin's Q adalah :

dimana :

$$
Q=\frac{M V E+D E B T}{T A}
$$

$\mathrm{Q} \quad=$ Nilai Perusahaan(Firm value)

MVE = Closing Price $\mathrm{x}$ saham beredar (Nilai Pasar Ekuitas)

DEBT $=$ Total Hutang

TA $\quad=$ Total Aktiva

Tingkat pengungkapan CSR pada laporan tahunan perusahaan yang dinyatakan dalam Corporate Social Responsibility Disclosure (CSRD). Formula untuk menghitung Pengungkapan CSR (Mardikanto, 2014) sebagai berikut:

Keterangan :

$$
C S R D=\frac{\mathrm{V}}{M} \times 100
$$

CSRD = Corporate Social Responsibility Disclosure Perusahaan

$\mathrm{V} \quad=$ Jumlah Item yang diungkapkan perusahaan

$\mathrm{M} \quad=$ Jumlah keseluruhan Item pengungkapan CSR

\subsection{Prosedur Analisis Data}

Prosedur analisis data yang digunakan dalam penelitian ini adalah sebagai berikut:

\subsubsection{Uji Asumsi Klasik}

Uji asumsi klasik dalam penelitian ini terdiri dari uji normalitas, uji multikolinieritas dan uji autokorelasi.

\subsubsection{Analisis Regresi Linier Berganda}

Metode analisis untuk mengetahui pengaruh GCG dan CSR terhadap nilai perusahaan yaitu dengan menggunakan persamaan Multiple Regressions. Pada penelitian ini, data diolah menggunakan aplikasi komputer yaitu SPSS versi 17.0 (Ghozali, 2009). Persamaan regresi linier berganda dalam penelitian ini adalah sebagai berikut:

$$
\begin{aligned}
& Y=a+b_{1} X_{1}+e \\
& Y=a+b_{2} X_{2}+e \\
& Y=a+b_{1} X_{1}+b_{2} X_{2}+e \\
& Y=a+b_{1} X_{1}+b_{2} X_{2}+b_{3} X_{1} X_{2}+e
\end{aligned}
$$




\subsubsection{Pengujian Model (Uji t)}

Pengujian ini dilakukan untuk mengetahui secara parsial apakah variabel bebas berpengaruh secara signifikan atau tidak terhadap variabel terikat (Ghozali, 2009). Kriteria pengujian yang digunakan adalah $\mathrm{H}_{0}$ ditolak dan $\mathrm{H}_{a}$ diterima apabila nilai signifikansi $<0,05$. Artinya variabel bebas secara parsial berpengaruh signifikan terhadap variabel terikat. Demikian sebaliknya.

\subsubsection{Pengujian Model (Uji F)}

Pengujian ini dilakukan untuk mengetahui apakah variabel bebas secara bersama-sama berpengaruh signifikan atau tidak terhadap variabel terikat (Ghozali, 2009). Kriteria pengujian yang digunakan adalah $\mathrm{H}_{0}$ ditolak dan $\mathrm{H}_{\mathrm{a}}$ diterima apabila sig. $\mathrm{F}<0,05$. Hal ini berarti variabel bebas secara simultan berpengaruh signifikan terhadap variabel terikat. Demikian sebaliknya.

\section{HASIL PENELITIAN}

\subsection{Hasil Uji Asumsi Klasik}

Tabel 1. Hasil Uji Asumsi Klasik

\begin{tabular}{|l|l|l|}
\hline \multicolumn{1}{|c|}{ Asumsi Klasik } & \multicolumn{1}{|c|}{ Hasil } & \multicolumn{1}{c|}{ Keterangan } \\
\hline $\begin{array}{l}\text { Normalitas } \\
\text { (Kolmogorov- } \\
\text { Smirnov) }\end{array}$ & Signifikansi 0,302 $>0,05$ & $\begin{array}{l}\text { Berdistribusi Normal, Lulus } \\
\text { Uji Normalitas }\end{array}$ \\
\hline $\begin{array}{l}\text { Multikolinieritas } \\
\text { (Variance Inflation } \\
\text { Factor) }\end{array}$ & $\begin{array}{l}\text { Nilai VIF dari kelima variabel } \\
\text { berkisar dari 1,183-2,175 yang } \\
\text { mana }<10\end{array}$ & Lulus Uji Multikolinieritas \\
\hline $\begin{array}{l}\text { Autokorelasi (Durbin } \\
\text { Watson) }\end{array}$ & $\begin{array}{l}\text { Nilai DW sebesar 2,183 } \\
\text { berada diantara dU dan 4-dU } \\
(1,8128<2,1830<2,8128) .\end{array}$ & Lulus Uji Autokorelasi \\
\hline
\end{tabular}

Sumber : Data diolah (Output SPSS) 


\section{NATIONALLY ACCREDITED JOURNAL - DECREE NO. 21/E/KPT/2018}

\subsection{Analisis Regresi Linier Berganda}

Tabel 2. Ringkasan Hasil Regresi

\begin{tabular}{|c|c|c|c|c|c|c|c|c|}
\hline $\begin{array}{c}\text { No. } \\
\text { Model }\end{array}$ & $\begin{array}{l}\text { GCG } \\
(\mathrm{X} 1)\end{array}$ & $\begin{array}{l}\text { CSR } \\
(\mathrm{X} 2)\end{array}$ & $\begin{array}{c}\text { GCG*CSR } \\
\left(X 1^{*} X 2\right)\end{array}$ & $\begin{array}{c}\text { Uji yang } \\
\text { Digunakan }\end{array}$ & Sig & Beta & $\mathbf{R}^{2}$ & Keterangan \\
\hline \multirow{4}{*}{1} & $\begin{array}{l}\text { Kepemilikan } \\
\text { Manajerial }\end{array}$ & \multirow{4}{*}{ - } & \multirow{4}{*}{ - } & \multirow{4}{*}{ Uji t } & \multirow{4}{*}{0,725} & \multirow{4}{*}{0,140} & \multirow{4}{*}{$0,4 \%$} & \multirow{4}{*}{ - } \\
\hline & $\begin{array}{l}\text { Kepemilikan } \\
\text { Institusional }\end{array}$ & & & & & & & \\
\hline & $\begin{array}{l}\text { Proporsi Dewan } \\
\text { Komisaris }\end{array}$ & & & & & & & \\
\hline & Komite Audit & & & & & & & \\
\hline \multirow{3}{*}{2} & $\begin{array}{l}\text { Kepemilikan } \\
\text { Institusional }\end{array}$ & \multirow{3}{*}{ - } & \multirow{3}{*}{ - } & \multirow{3}{*}{ Uji t } & \multirow{3}{*}{0,725} & \multirow{3}{*}{0,140} & \multirow{3}{*}{$0,4 \%$} & \multirow{3}{*}{ - } \\
\hline & $\begin{array}{l}\text { Proporsi Dewan } \\
\text { Komisaris }\end{array}$ & & & & & & & \\
\hline & Komite Audit & & & & & & & \\
\hline \multirow[b]{2}{*}{3} & $\begin{array}{l}\text { Kepemilikan } \\
\text { Institusional }\end{array}$ & \multirow[b]{2}{*}{ - } & \multirow[b]{2}{*}{ - } & \multirow{2}{*}{ Uji t } & \multirow{2}{*}{0,332} & \multirow{2}{*}{0,399} & \multirow{2}{*}{$3 \%$} & \multirow{2}{*}{$\begin{array}{c}\mathrm{R}^{2} \\
\text { meningkat } \\
\text { Sig } \\
\text { menurun }\end{array}$} \\
\hline & $\begin{array}{l}\text { Proporsi Dewan } \\
\text { Komisaris }\end{array}$ & & & & & & & \\
\hline 4 & $\begin{array}{l}\text { Kepemilikan } \\
\text { Institusional }\end{array}$ & - & - & Uji t & 0,409 & 0,483 & $2,2 \%$ & $\begin{array}{c}\mathrm{R}^{2} \\
\text { menurun }\end{array}$ \\
\hline 5 & $\begin{array}{l}\text { Proporsi Dewan } \\
\text { Komisaris }\end{array}$ & - & - & Uji t & 0,344 & 0,955 & $2,9 \%$ & $\begin{array}{c}\text { Beta } \\
\text { meningkat }\end{array}$ \\
\hline 6 & - & CSRD & - & Uji t & 0,857 & $-0,472$ & $0,1 \%$ & - \\
\hline 7 & $\begin{array}{l}\text { Proporsi Dewan } \\
\text { Komisaris }\end{array}$ & CSRD & - & Uji F & 0,639 & 0,552 & $2,9 \%$ & - \\
\hline 9 & $\begin{array}{l}\text { Proporsi Dewan } \\
\text { Komisaris }\end{array}$ & CSRD & GCG $^{*}$ CSRD & Uji F & 0,681 & 0,932 & $5 \%$ & $\begin{array}{c}\mathrm{R}^{2} \\
\text { meningkat }\end{array}$ \\
\hline
\end{tabular}

Sumber : Data diolah (Output SPSS)

\section{PEMBAHASAN}

Hasil Pengujian Hipotesis $1\left(\mathrm{H}_{1}\right)$

Dengan menggunakan Proporsi Dewan Komisaris (PDK) sebagai proksi tunggal diperoleh beta sebesar 0,955 yang merupakan beta tertinggi dibandingkan dengan nilai beta model GCG lainnya. Kemudian tingkat signifikansi sebesar 0,344. Dari berbagai uji coba, ditemukan bahwa GCG dengan proksi PDK memiliki signifikansi dan $\mathrm{R}^{2}$ yang lebih baik serta beta yang lebih tinggi bila dibandingkan dengan model lainnya. Dengan demikian, dapat disimpulkan bahwa model GCG dengan proksi PDK merupakan model GCG yang paling fit karena memiliki nilai signifikansi yang mendekati 0,05 yaitu 0,344 dan nilai $\mathrm{R}^{2}$ sebesar 2,9\% serta nilai beta sebesar 0,955. Hal ini berarti bahwa $\mathrm{H}_{0}$ diterima dan $\mathrm{H}_{1}$ ditolak yang menunjukkan Good Corporate Governance $\left(\mathrm{X}_{1}\right)$ berpengaruh positif tidak signifikan terhadap nilai perusahaan $(\mathrm{Y})$.

Hasil Pengujian Hipotesis $2\left(\mathrm{H}_{2}\right)$

Model persamaan regresi antara CSR terhadap nilai perusahaan yaitu $\mathrm{Y}=2,096$ 0,472X 2 . Dari model tersebut dapat diketahui bahwa CSR berpengaruh negatif terhadap nilai perusahaan. Bila CSR bernilai 0 maka nilai perusahaan akan bernilai 2,096 dan setiap 
tambahan 1 nilai CSR akan menurunkan nilai perusahaan sebesar 0,472. Kemudian, nampak pula nilai signifikansi sebesar 0,857 >0,05 yang berarti pengaruh tersebut tidak signifikan. nilai $\mathrm{R}^{2}$ adalah sebesar 0,001 atau sebesar $0,1 \%$. Artinya CSR hanya mampu menjelaskan perubahan pada variabel dependen (nilai perusahaan) sebesar 0,1\% dan 99,9\% dijelaskan oleh variabel lain di luar penelitian ini. Dengan demikian, dapat disimpulkan bahwa $\mathrm{H}_{0}$ diterima dan $\mathrm{H}_{2}$ ditolak, yang berarti CSR $\left(\mathrm{X}_{2}\right)$ berpengaruh negatif tidak signifikan terhadap nilai perusahaan.

$>$ Hasil Pengujian Hipotesis $3\left(\mathrm{H}_{3}\right)$

Nilai signifikansi F sebesar 0,639 lebih besar dari 0,05, hal ini berarti bahwa GCG dan CSR secara simultan tidak memiliki pengaruh yang signifikan terhadap nilai perusahaan. Selain itu, GCG dan CSR secara simultan memiliki nilai koefisien determinasi sebesar 0,029 atau sebesar 2,9\%. Dengan demikian, dapat disimpulkan bahwa $\mathrm{H}_{0}$ diterima atau $\mathrm{H}_{3}$ ditolak yang berarti GCG dan CSR secara simultan tidak berpengaruh signifikan terhadap nilai perusahaan.

$>$ Hasil Pengujian Hipotesis $4\left(\mathrm{H}_{4}\right)$

Diketahui bahwa nilai koefisien determinasi sebesar 0,050 atau sebesar 5\%. Sedangkan nilai koefisien determinasi GCG yang diproksikan dengan Proporsi Dewan Komisaris (PDK) terhadap nilai perusahaan tanpa adanya moderasi CSR diketahui sebesar 2,9\%. Hal ini mengindikasikan bahwa dengan adanya moderasi CSR terjadi peningkatan nilai koefisien determinasi $\left(\mathrm{R}^{2}\right)$ dari 2,9\% menjadi 5\%. Dengan demikian, dapat disimpulkan bahwa $\mathrm{H}_{4}$ diterima dan $\mathrm{H}_{0}$ ditolak, yang berarti CSR mampu memoderasi secara positif (memperkuat) pengaruh GCG terhadap nilai perusahaan.

Menurut Prastuti dan Budiasih (2015), investor di Indonesia cenderung membeli saham dengan tujuan untuk memperoleh capital gain (peningkatan harga saham) ataupun deviden, tanpa memperhatikan keberlangsungan perusahaan dalam jangka panjang. Sedangkan CSR merupakan strategi jangka panjang perusahaan dalam usaha untuk menjaga keberlangsungan perusahaan, dan pengaruh dari CSR tidak dapat dirasakan dalam jangka pendek.

Dalam perhitungan nilai perusahaan digunakan rumus Tobin'Q. Nilai Tobin's $Q$ atau rasio $Q$ pada umumnya dapat dihitung dengan membagi nilai pasar suatu perusahaan dengan total asset yang dimiliki oleh perusahaan tersebut. Nilai pasar perusahaan diperoleh dengan menjumlahkan nilai pasar saham yang beredar dan hutang, sehingga harga saham perusahaan memiliki peranan yang sangat penting dalam menentukan tinggi rendahnya nilai suatu perusahaan yang diukur dengan Tobin's Q.

Variabel GCG dan CSR tidak termasuk ke dalam faktor-faktor yang dapat mempengaruhi perubahan harga saham. Dimana dalam penelitian ini, harga saham memiliki peranan yang penting yaitu sebagai pembilang dalam rumus Tobin' $Q$ yang digunakan dalam menentukan nilai perusahaan. Semakin tinggi harga saham maka akan semakin tinggi pula nilai dari suatu perusahaan. Namun demikian, dalam penelitian ini ditemukan bahwa CSR mampu memoderasi hubungan antara GCG dengan nilai perusahaan. Menurut Murwaningsari (2009) Corporate Social Responsibility mempunyai keterkaitan yang erat dengan Good Corporate Governance. Tanggung jawab sosial berorientasi kepada para stakeholders, hal ini sejalan dengan prinsip-prinsip utama Good Corporate Governance yaitu responsibility, sedangkan pengungkapan pelaksanaan tanggung jawab sosial perusahaan sejalan dengan prinsip transparansi. 


\section{KESIMPULAN} berikut :

Berdasarkan hasil penelitian dan pembahasan, maka dapat ditarik kesimpulan sebagai

1. Variabel Good Corporate Governance (GCG) memiliki pengaruh positif tidak signifikan terhadap nilai perusahaan. Hal ini dapat dimungkinkan karena praktek GCG pada perusahaan memang dilaksanakan, akan tetapi implementasinya masih belum diterapkan oleh perusahaan secara penuh sesuai dengan prinsip-prinsip GCG. Perubahan dalam nilai perusahaan sangat dipengaruhi oleh perubahan harga saham, sementara GCG tidak termasuk ke dalam faktor yang dapat merubah tingkat harga saham.

2. Variabel Corporate Social Responsibility (CSR) memiliki pengaruh dengan arah negatif dan tidak signifikan terhadap nilai perusahaan. Konsep CSR tidak dilaksanakan secara penuh oleh perusahaan. Penilaian konsep CSR dilakukan dengan self assessment, dibutuhkan sebuah lembaga khusus untuk mengaudit pelaporan CSR perusahaan sehingga dapat lebih tepat dan terpercaya sesuai dengan peraturan yang berlaku.

3. Proporsi Dewan Komisaris (PDK) merupakan proksi terbaik untuk membentuk nilai GCG. Hal ini dikarenakan hasil perhitungan regresi GCG yang diproksikan dengan PDK terhadap nilai perusahaan memperoleh signifikansi, beta dan koefisien determinasi terbaik dibandingkan ketiga proxy GCG yang lainnya.

4. PDK menjadi proksi GCG terbaik dalam studi kasus indeks SRI-KEHATI. Hal ini disebabkan oleh banyaknya BUMN yang tergabung dalam indeks tersebut. Adanya pengawasan dari komisaris independen dapat mengawasi setiap kegiatan direksi untuk mencegah terjadinya penyalahgunaan sumber daya serta penyelewengan.

5. CSR mampu memoderasi hubungan antara GCG dengan nilai perusahaan. CSR mempunyai keterkaitan yang erat dengan GCG, keduanya memiliki kedudukan yang kuat dalam dunia bisnis dan memiliki hubungan satu dengan yang lainnya. Hal ini sejalan dengan prinsip-prinsip utama GCG yaitu responsibility, sedangkan pengungkapan pelaksanaan CSR sejalan dengan prinsip transparansi.

6. Pada dasarnya Indeks SRI-Kehati mendasarkan pemilihan perusahaan yang listed di dalamnya atas kemampuan sustainability perusahaan, tata kelola perusahaan, lingkungan, keterlibatan masyarakat, perilaku bisnis, sumber daya manusia dan Hak Asasi Manusia (HAM). Hal ini dibuktikan secara empiris bahwa sebagian besar perusahaan dalam indeks SRI-KEHATI merupakan perusahaan BUMN yang tidak hanya berorientasi pada perolehan laba (Profit oriented), namun juga sangat memerhatikan aspek-aspek sosial sesuai dengan fungsinya sebagai perusahaan BUMN.

7.

\section{DAFTAR PUSTAKA}

Amanti, L. (2012). Pengaruh Good Corporate Governance Terhadap Nilai Perusahaan dengan Pengungkapan Corporate Sosial Responsibility sebagai Variabel Pemoderasi (Studi Kasus Pada Perusahaan Rokok yang Terdaftar di BEI). Jurnal Akuntansi Unesa, Vol. 30, No. 3: 65-88

Arifin, A. (2012). Membaca Saham. Yogyakarta: Andi

Aziz, M. A. (2014). Manajemen. Bandung: Mardika Group

Daniri, A. (2014). Good Corporate Governance, Konsep dan Penerapannya Dalam Konteks Indonesia. Jakarta: PT Ray Indonesia 
Elkington, J. (1998). Cannibals With Forks: The Tripple Bottom Line in 21 st Century Business. Gabriola Island. BC: New Society Publishers

Etty, M. (2009). Hubungan Corporate Governance, Corporate Social Responsibilities dan Corporate Financial Performance. Jakarta: Universitas Trisakti

Faisal. (2005). Analisis Agency Costs, Struktur Kepemilikan dan Mekanisme Corporate Governance. Denpasar: Simposium Nasional Akuntansi VII

Ghozali, I. (2009). Aplikasi Analisis Multivariate dengan program SPSS. Semarang: BP Universitas Diponegoro.

Hamdani. (2016). Good Corporate Governance, Tinjauan Etika dalam Praktik Bisnis. Tanggerang: Mitra Wacana Media

Hanum, L. (2012). Pengaruh Good Corporate Governance Terhadap Nilai Perusahaan Dengan Corporate Social Responsibility(CSR) Sebagai Variabel Moderasi (Studi Empiris Pada Perusahaan Manufaktur yang Terdaftar di BEI). E-Jurnal STKIP PGRI Sumatera Barat, Vol. 1, No. 4: 117-132

Herawati, V. (2008). Peran Praktek Corporate Governance Sebagai Moderating Variable Dari Pengukuran Earnings Management. Pontianak : SNA XI

Indahningrum dkk., (2009). Pengaruh Kepemilikan Manajerial, Kepemilikan Institusional, Dividen, Pertumbuhan Perusahaan, Free Cash Flow dan Profitabilitas terhadap Kebijakan Hutang Perusahaan. Jurnal Bisnis dan Akuntansi, Vol. 11, No. 3: 189-207

Keputusan Menteri BUMN Nomor 117/2002 mengenai Good Corporate Governance.

Kinanti, T. (2015). Pengaruh Good Corporate Governance Terhadap Nilai Perusahaan Yang Terdaftar Pada Indeks Sri-Kehati. Jurnal Ilmu dan Riset Akuntansi, Vol. 4, No. 7:157-180

Kusharyanti. (2003). Temuan Penelitian Mengenai Kualitas Audit dan Kemungkinan Topik Penelitian di Masa Datang. Jurnal Akuntansi dan Manajemen, Vol. 1, No. 2: 28-50.

Kusumadilaga, R. (2010). Pengaruh Corporate Social Responsibility Terhadap Nilai Perusahaan Dengan Profitabilitas Sebagai Variabel Moderating (Studi Empiris pada Perusahaan Manufaktur yang Terdaftar di Bursa Efek Indonesia). JurnalSkripsi.Com diakses pada tanggal 16 November 2017

Mardani, R. (2017). M Jurnal Ekonomi dan Bisnis : Penggunaan EViews - Uji Asumsi Klasik Regresi Linier. https://mardanijournal.wordpress.com/2017/04/26/ uji-asumsiklasik-menggunakan-eviews/\#more-583 diakses pada tanggal 22 Mei 2018

Mardikanto, T. (2014). Corporate Social Responsibility. Bandung: Alfabeta

Prastowo, Joko dan Huda, Miftahul. (2011). Corporate Social Responsibility: Kunci Meraih Kemuliaan Bisnis. Yogyakarta: Penerbit Samudra Biru

Prastuti, K., dan Budiasih, N. (2015). Pengaruh Good Corporate Governance pada Nilai Perusahaan dengan Moderasi Corporate Social Responsibility. E-Jurnal Akuntansi Universitas Udayana, Vol. 13, No. 5: 114-129

Rachmad S, R. (2012). Analisis Perbedaan Harga dan Volume Saham Sebelum dan Sesudah Pengumuman Indonesia Sustainability Reporting Award (ISRA), JurnalSkripsi.Com diakses pada tanggal 13 November 2017

Retno, D. dan Denies, P., (2012). Pengaruh Good Corporate Governance dan Pengungkapan Corpoate Social Responsibility terhadap Nilai Perusahaan (Studi Empiris pada Perusahaan yang Terdaftar di BEI Periode 2007-2010). Jurnal Nominal, Vol. 1, No. 1: 84-103 
Rustiarini, N. W. (2010). Pengaruh Corporate Governance Pada Hubungan Corporate Social Responsibility dan Nilai Perusahaan. Simposium Nasional Akuntansi XIII. Universitas Jenderal Sudirman Purwokerto

Scoot, W. R. (1997). Financial Accounting Theory. $3^{\text {rd }}$ Edition. Toronto: Prentice-Hall

Setiawan, B. (2013). Implementasi Pelaksanaan Corporate Social Responsibility (CSR) Sebagai Kewajiban Hukum Perusahaan pada PT. Telkom: Purwokerto

Setyaningrum, A. N. (2012). Pengaruh Employee Stock Ownership Program (ESOP) terhadap Kualitas Implementasi Corporate Governance dan Kinerja Perusahaan. http://jimfeb.ub.ac.id/index.php/jimfeb/article/view/248 diakses pada tanggal 10 November 2017

Sugiyono. (2007). Metode Penelitian Bisnis. Bandung: Alfabeta

Sule, E. T., dan Saefullah, K. (2005). Pengantar Manajemen. Jakarta: Kencana Prenada Media Group

Sutedi, A. (2012). Good Corporate Governance. Jakarta: Sinar Grafika

Undang-Undang No. 32 Tahun 2009 tentang Perlindungan dan Pengelolaan Lingkungan Hidup

Undang-Undang BUMN Pasal 31 Tahun 2012

Undang-Undang Nomor 16 Tahun 2001 tentang Yayasan

Undang-Undang Nomor 28 Tahun 2004 tentang Yayasan

Undang-Undang Perseroan Terbatas No. 40 Pasal 74 Tahun 2007

Wardhani, D. (2008). Media Relations Sarana Membangun Reputasi Perusahaan. Jakarta: Graha Ilmu

Weston, F. J dan Copeland. T. E., (2004). Manajemen Keuangan. Jilid 2. Jakarta: Binarupa Aksara Publisher

Wida P.D, N. P., dan Suartana, I W.. (2014). Pengaruh Kepemilikan Manajerial dan Kepemilikan Institusional terhadap Nilai Perusahaan. e-Jurnal Akuntansi Universitas Udayana, Vol. 9, No. 3:575-590 